\title{
WATER QUALITY INDICATORS FOR ENVIRONMENTAL AND RESISTANCE PROFILE OF Escherichia coli STRAINS ISOLATED IN RIO CASCAVEL, PARANÁ, BRAZIL
}

\section{MARINÊZ DE SOUZA ${ }^{1}$, FABIANA G. DA S. PINTO ${ }^{2}$, THOMAS K. FRUET ${ }^{1}$, PITÁGORAS A. PIANA ${ }^{3}$, ALEXANDRE C. DE MOURA ${ }^{4}$}

\begin{abstract}
In this article it was evaluated the quality of water in the Cascavel river, in the city of Cascavel - Paraná using microbiological indicators, physical and chemical pollution and susceptibility / resistance in strains of Escherichia coli isolated antimicrobial trade. The water sampling was conducted between 2010-July and 2011-June at three points: a) near the source, b) urban area, c) rural area. The samples were analyzed for physical, chemical and microbiological variables: temperature, $\mathrm{pH}$, color, turbidity, electrical conductivity, total nitrogen and total phosphorus, total coliforms (CT), fecal coliform (CTe) and Escherichia coli. Tests were also performed to nine antimicrobial commercial resistances. The variables studied indicated that the Cascavel river water was presented at disagreement with the resolution 357/2005 CONAMA (class I), ranking in the index as regular water quality. The physical, chemical and rainfall did not affect the growth of CT and CTe, with higher counts of E. coli in the urban area. The greatest resistance profiles of the strains of $E$. coli isolated from Cascavel river water was found in section 2, the urban area as a probable consequence of human influence on water quality.
\end{abstract}

KEYWORDS: water resources, physical and chemical parameters, water pollution, coliforms, microbiology, WQI.

\section{QUALIDADE DA ÁGUA POR INDICADORES AMBIENTAIS E PERFIL DE RESISTÊNCIA ANTIMICROBIANA DE CEPAS DE Escherichia coli ISOLADAS NO RIO CASCAVEL, PARANÁ}

RESUMO: Neste estudo, foi avaliada a qualidade da água do Rio Cascavel, município de Cascavel, Paraná, utilizando indicadores microbiológicos, físicos e químicos de poluição e a suscetibilidade/resistência das cepas de Escherichia coli isoladas aos antimicrobianos comerciais. As amostragens de água foram realizadas entre julho-2010 e junho-2011, em três pontos: a) próximo à nascente; b) área urbana; c) área rural. As amostras foram analisadas quanto às variáveis físicas, químicas e microbiológicas: temperatura, $\mathrm{pH}$, cor, turbidez, condutividade elétrica, nitrogênio total e fósforo total, coliformes totais (CT), coliformes termotolerantes (CTe) e Escherichia coli. Foram realizados, também, testes de resistência a nove antimicrobianos comerciais. As variáveis estudadas indicaram que a água do Rio Cascavel apresenta-se em desacordo com a resolução 357/2005 do CONAMA (classe I), classificando-se como regular no índice de qualidade de água. As variáveis físicas, químicas e a precipitação não influenciaram no crescimento de CT e CTe, sendo maiores as contagens de E. coli na área urbana. Os maiores perfis de resistência das cepas de E. coli, isoladas das águas do Rio Cascavel, foram encontrados no ponto 2, área urbana, como provável consequência da influência humana sobre a qualidade da água.

PALAVRAS-CHAVE: recursos hídricos, variáveis físicas e químicas, poluição hídrica, coliformes, microbiologia, IQA.

\footnotetext{
${ }^{1}$ Biólogo, Mestre em Conservação e Manejo de Recursos Naturais, UNIOESTE, Cascavel - PR

${ }^{2}$ Bióloga, Profa. Doutora, Laboratório de Biotecnologia Agrícola, UNIOESTE, Cascavel - PR, fabiana.pinto@unioeste.br

${ }^{3}$ Eng $^{\circ}$ de Pesca, Prof. Doutor, UNIOESTE, Toledo - PR.

${ }^{4}$ Biólogo, Prof. Mestre, Universidade Federal da Fronteira Sul/UFFS, PR.

Recebido pelo Conselho Editorial em: 25-6-2012

Aprovado pelo Conselho Editorial em: 18-11-2013
} 


\section{INTRODUCTION}

The water quality in many rivers has decreased due to the dumping of pollutants from point and diffuse source, and in cities where there is not a system of efficient sewage treatment, the domestic sewage is a major source of pollution, stimulating growth of bacteria and other microorganisms, including those of fecal origin (GONCHARUK, 2007, NASH et al., 2009).

The main groups of bacteria used to indicate pollution levels in water are total coliform (CT) and thermotolerant (CTe), and more specifically Escherichia coli (PLUMMER \& LONG, 2007; SILVA et al., 2010.). Besides the presence of coliforms, the evaluation of the resistance of microorganisms against various antimicrobial suitable for human population, has been indicated to evaluate the anthropogenic contamination of a wellspring (SILVA et al., 2010).

Other variables are important in the study of water quality, among them physical and chemical, which provide information about the capacity of water to maintain the growth of algae and other aquatic life, and make it possible to determine the impacts generated by anthropogenic activities such as discharges of domestic sewage, industrial, commercial, urban roads and leaching of agricultural soils (LIBÂNIO, 2005; MANAHAN, 2006). Another method used as a support tool in characterization studies of the quality of river water is the Water Quality Index - WQI, which takes into account the physical, chemical and microbiological components seamlessly.

In this context, the watershed of the Cascavel River (BHRC) located west of Paraná, has a drainage area of $50.11 \mathrm{~km}^{2}$ length of $17.5 \mathrm{~km}$ and a maximum height of $767 \mathrm{~m}$ and minimum of $718 \mathrm{~m}$, being responsible for about $80 \%$ of the total production of the public water supply system of Cascavel city, Brazil, making its relevance monitoring (CASCAVEL, 2011). Among the main problems identified in public supply rivers, located in urban areas, is the lack of riparian vegetation in both urban and rural areas, resulting in the development of erosion and silting up of the watershed processes that affect the water supply to riverside population (CREPALLI, 2007).

Thus, this study aimed to: a) evaluate the quality of the Cascavel river water in Cascavel, Paraná State, Brazil, in three collection sections using microbiological, physical and chemical water quality indicators ; b) check the physical factors and chemicals that influence the growth levels of the groups of micro-organisms and CT and CTe; c) Application of antimicrobial resistance index (IRA) to assess the susceptibility/resistance of strains of E. coli to commercial antimicrobials, correlating them with the possible pollution sources.

\section{MATERIALS AND METHODS}

The study was conducted in the hydrographic basin of Cascavel river (BHRC), collecting samples monthly during the period from July 2010 to June 2011, comprising three points distributed along the Cascavel River (Figure 1). Point 1 (P1) represents the Spillway Lake, near the nascent

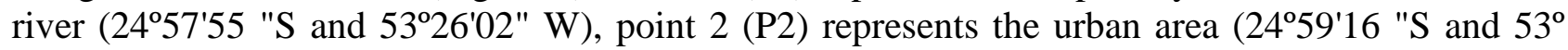
$26^{\prime} 13^{\prime \prime} \mathrm{W}$ ) and point 3 (P3) represents the nearest water catchment of the rural area station of the county $\left(25^{\circ} 01^{\prime} 43.66\right.$ "S and 53 $\left.28^{\prime} 02^{\prime \prime} \mathrm{W}\right)$.

The collected water samples were stored in glass bottles of $300 \mathrm{~mL}$, previously sterilized in an autoclave at $121^{\circ} \mathrm{C}$ for $15 \mathrm{~min}$. After collecting the samples (rejoinders by), the bottles were transported in cool boxes to the laboratory of Microbiology and Biotechnology Agricultural and Environmental Sanitation of the State University of West Paraná, Campus Cascavel for performing microbiological, physical and chemical analysis. Subsequently, values of monthly precipitation were obtained from the SIMEPAR/Curitiba.

Microbiological analysis of CT and CTe were performed according to the methodology of the Most Probable Number (MPN) described by SILVA et al. (2007). The physical and chemical analyzes of temperature, $\mathrm{pH}$, color, turbidity, electrical conductivity, total nitrogen and total phosphorus followed the methodology described in Standard Methods for the Examination of Water and Wastewater (APHA, 1998). The results were compared with the parameters required by 
Ordinance No. 2914 of the Ministry of Health (MS) (BRAZIL, 2011) on the standard of potability of water and Resolution No. 357 (BRAZIL, 2005) of the National Environmental Council (CONAMA) establishing guidelines on conditions and standards for effluent discharge and conditions for bathing.

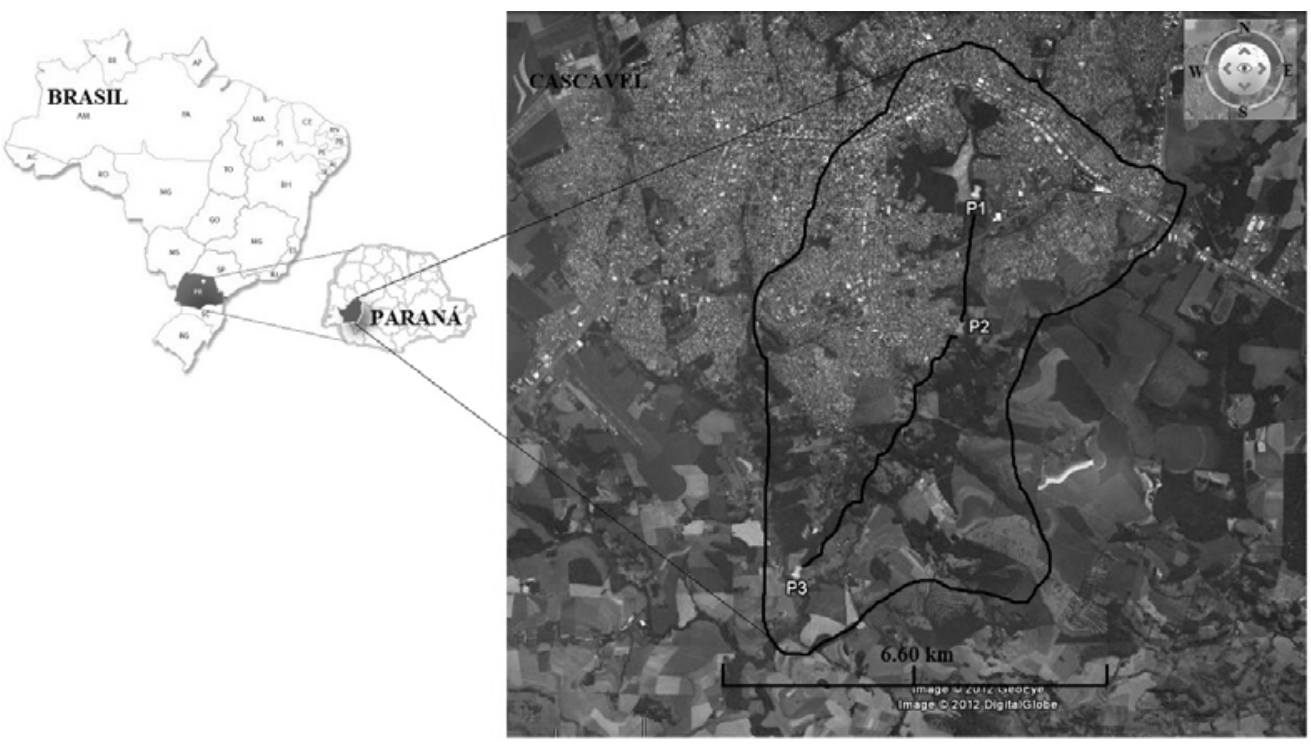

FIGURE 1. Location of the study area. River Basin Cascavel, Paraná, Brazil, with the water collection points. P1: Spillway, P2: Urban. area , P3: Rural area.

In the characterization of water quality index - IQA used the modified index by the Company of Environmental Sanitation Technology of the State of São Paulo (CETESB, 2011) where the index values range from 0 to 100 in categories: very good $(79<\mathrm{IQA} \leq 100)$, good $(51<\mathrm{IQA} \leq 79)$, regular $(36<\mathrm{IQA} \leq 51)$, poor $(19<\mathrm{IQA} \leq 36)$ and awful $(\leq 19 \mathrm{IQA})$.

The antimicrobial resistance profile was evaluated according to the recommendations of the Clinical and Laboratory Standards Institute (CLSI) (CLSI, 2007). The tested antibiotics were: chloramphenicol (30 mg), sulphazotrim (23.75 $\mu \mathrm{g}+25 \mu \mathrm{g})$, gentamicin $(10 \mu \mathrm{g})$, ampicillin $(10 \mu \mathrm{g})$, cephalothin (30 $\mu \mathrm{g} 0)$, imipenem $(10 \mu \mathrm{g})$, tetracycline $(30 \mu \mathrm{g})$, streptomycin $(10 \mu \mathrm{g})$ and penicillin $(10 \mu \mathrm{g})$. Were used as reference strains Escherichia coli ATCC 25922 (American Type Culture Collection). Strains were classified as susceptible or resistant according to the data in Table 2A, document M100-S17 CLSI (2007), with analyzes performed in triplicate.

For susceptibility / resistance of strains of $E$. coli to commercial antimicrobial the index of resistance to antimicrobials (IRA) was calculated for each strain isolated of the month in which $E$. coli was present. The IRA of each sample was defined as the ratio between the number of samples resistant to the antimicrobials tested and the total number of antimicrobials. For each point of the river IRAp was determined being defined as the ratio between the number of resistant samples for antimicrobial evaluated per collected point and the total number of tests performed at this point, according to the methodology proposed by WEBSTER et al. (2004) and SILVA et al. (2010).

We used analysis of variance for the main effects, followed by comparison of average by Tukey test for: a) comparative purposes with the laws b) assess significant differences between the variables c) Comparison of CT and CTe between three regions of the river and collection month.

To identify the physical and chemical variables that could influence each other, a multivariate approach was adopted, the Principal Component Analysis (ACP). The data were transformed to $\log _{10}$ to approximate frequency distributions to be normal. The test of Kaiser-Guttman (eigenvalue> 1) was used for retention and interpretation of the axes of ACP (OLIVEIRA et al., 2008). 
Evaluating the effects of physical and chemical variables on CT and CTe, scores of retained axes were correlated in their abundances (for not being linear, the data were also transformed into log10) by Pearson and Spearman correlation, were considered significant correlations with $\mathrm{p}<0.05$ in both tests. In addition to physical and chemical factors, we assessed the possible influence of precipitation on CT and h CTe with correlation cited (precipitation was not included in the ACP for being unique for the three regions).

The values of IRA (index of resistance to antimicrobials) were compared between regions of the river through the analysis of unifactorial variance.

\section{RESULTS AND DISCUSSION}

The variance analysis has shown that the physical variables, color and electrical conductivity differ from P1to P2 and P3 for the test of significance of 5\% (Table 1). For color there was significant difference between P1 and P3, has being observed the highest values for rural area (P3). Regarding the electrical conductivity there was significant difference in $\mathrm{P} 1$ with the other points (P2 and P3); in P1 the lowest values has being observed.

Since pollution by discharges of domestic sewage and / or industrial (point source pollution) and leaching of urban roads occur on a larger scale in the urban area (P1 and P2), the color values for P3 can then be assigned to the dump organic effluents of agricultural origin in this region (diffuse pollution), and to a lesser extent the decomposition of organic matter of vegetable origin (LIBÂNIO, 2005; ANDRADE et al., 2007; LUCAS et al., 2010). As P1, despite of representing urbanized area, is located in the region of the river's source, one can say that it suffered minor influence of anthropogenic activities compared to P2.

The electrical conductivity reflects a direct relationship with the presence of dissolved salts in the form of electrolytic ally dissociated ions. This fact explains the lower results of electrical conductivity found in P1, since these ions, in most cases, originate from industrial discharges, consumption of salts in residence, commerce or decomposition of rocks (CREPALLI, 2007), these factors show higher performance in P2 (urban area) and P3 (rural area).

TABLE 1. Mean values and standard deviation of the microbiological variables, physical and chemical sampling point by the river Cascavel, PR.

\begin{tabular}{|c|c|c|c|c|}
\hline Variáveis & P1 & P2 & P3 & ${ }^{1}$ CONAMA \\
\hline${\text { Temperature } \mathrm{C}^{0}}^{0}$ & $21.08 \pm 3.29^{\mathrm{a}}$ & $19.33 \pm 3.23^{\mathrm{a}}$ & $18.42 \pm 3.48^{\mathrm{a}}$ & - \\
\hline $\mathrm{pH}$ & $6.6 \pm 0.44^{\mathrm{a}}$ & $6.93 \pm 0.30^{\mathrm{a}}$ & $6.95 \pm 0.8^{\mathrm{a}}$ & - \\
\hline Color (mgPt-CO/L) & $66.51 \pm 20.29^{a}$ & $119.0 \pm 92.51^{\mathrm{ab}}$ & $153.33 \pm 104.98^{b}$ & 75 \\
\hline Turbidity (NTU) & $21.96 \pm 32.04^{\mathrm{a}}$ & $29.49 \pm 32.38^{\mathrm{a}}$ & $50.76 \pm 56.98^{\mathrm{a}}$ & 100 \\
\hline Cond. electric $(\mu \mathrm{S} / \mathrm{cm})$ & $52.69 \pm 6.22^{\mathrm{a}}$ & $67.93 \pm 11.67^{\mathrm{b}}$ & $67.75 \pm 12.56^{\mathrm{b}}$ & - \\
\hline total nitrogen $(\mathrm{mg} / \mathrm{L})$ & $1.03 \pm 1.55^{\mathrm{a}}$ & $0.96 \pm 1.53^{\mathrm{a}}$ & $0.84 \pm 1.42^{\mathrm{a}}$ & 3.70 \\
\hline total phosphorus (mg/L) & $0.13 \pm 0.08^{\mathrm{a}}$ & $0.11 \pm 0.04^{\mathrm{a}}$ & $0.12 \pm 0.05^{a}$ & 0.03 \\
\hline CT $(\mathrm{NMP} / 100 \mathrm{~mL})^{*}$ & $3.5 \pm 1.50^{\mathrm{a}}$ & $3.84 \pm 1.53^{\mathrm{a}}$ & $3.66 \pm 1.40^{\mathrm{a}}$ & - \\
\hline CTe (NMP/100 mL)* & $2.81 \pm 0.40^{\mathrm{a}}$ & $3.45 \pm 0.38^{b}$ & $3.18 \pm 0.27^{\mathrm{ab}}$ & 3.40 \\
\hline
\end{tabular}

Averages horizontally followed by the same letter do not differ statistically at the $5 \%$ level of significance by the Tukey test. P1/P2/P3: collection points; pH: hydrogen potential; Cond: conductivity, CT: Coliforms; CTe: coliform thermotolerant. * Original values transformed to $\log (\mathrm{x}+1)^{1}$ maximum standards limit of water quality described by CONAMA Resolution 357 (2005) Class I.

Comparing the results obtained in the microbiological, physical and chemical analysis with the standards established by Resolution No. 357 of CONAMA (2005) class I, it is observed that CTe and color in sections 2 and 3, and total phosphorus in 1, 2 and 3 do not meet the parameters of the legislation cited. These results are probably due to anthropogenic activities along the river under study, with the total phosphorus and color, relating to sewage of human origin (LIBÂNIO, 2005; GONÇALVES, 2009). It is also suggested that this watercourse has a great chance of becoming 
eutrophic being phosphorus appointed as the main factor responsible for the eutrophication of aquatic systems (CORADI et al., 2009).

According to the classification of freshwaters under the Resolution No. 357 of CONAMA (2005), P1, P2 and P3 were found unfit for bathing because they have higher values than $1000 \mathrm{MPN} / \mathrm{mL}$ for group CTe. Furthermore, the high turbidity values can influence the effectiveness of the disinfection process in water treatment plants compromising the drinking water (SCHÄFER et al., 2009).

The unsatisfactory microbiological quality obtained in this study agrees with the observations by MOURA et al. (2009) for the monitoring of this same river in the period 2003-2006, being verified a high rate of contamination by CT and CTe.

Classification of the IQA, the three sampling stations found rates near: P1 43.63, P2 44.15, and P3 39.43, which classifies the river studied in the regular category of water quality. According ZANINI et al. (2010) human activities reduce the quality of water bodies, so the results were expected, since the Cascavel river bathes a region besides populous, is industrial and commercial hub, receiving effluent from agricultural, commercial, metallurgical and food industries (dairy, slaughterhouses and fridges) (MOURA et al., 2009).

In principal component analysis, which seeks to assess associations between variables, indicating the participation of the individual physical, chemical and microbiological factors on water quality, three axes were retained with eigenvalues greater than one for interpretation, which together represented 69\% of environmental variability (Figure 2).

The first axis explained 31\% of the variability and the variables that contributed negatively to the formation of this axis were turbidity and water color, with a coefficient of correlation higher than 0.8. This component reflects the content of organic and inorganic matter present in water (OLIVEIRA et al., 2008; MOURA et al., 2009).

In the second axis conductivity contributed positively and negatively, total phosphorus explaining $22 \%$ of variability. This component suggests influence of organic pollution, indicative of anthropogenic activities on water quality (ANDRADE et al., 2007). In the third axis pH and temperature variables contributed positively to the formation, explaining $16 \%$ of the variability, allowing ideal environmental conditions for growing micro-organisms groups of CT and CTE.
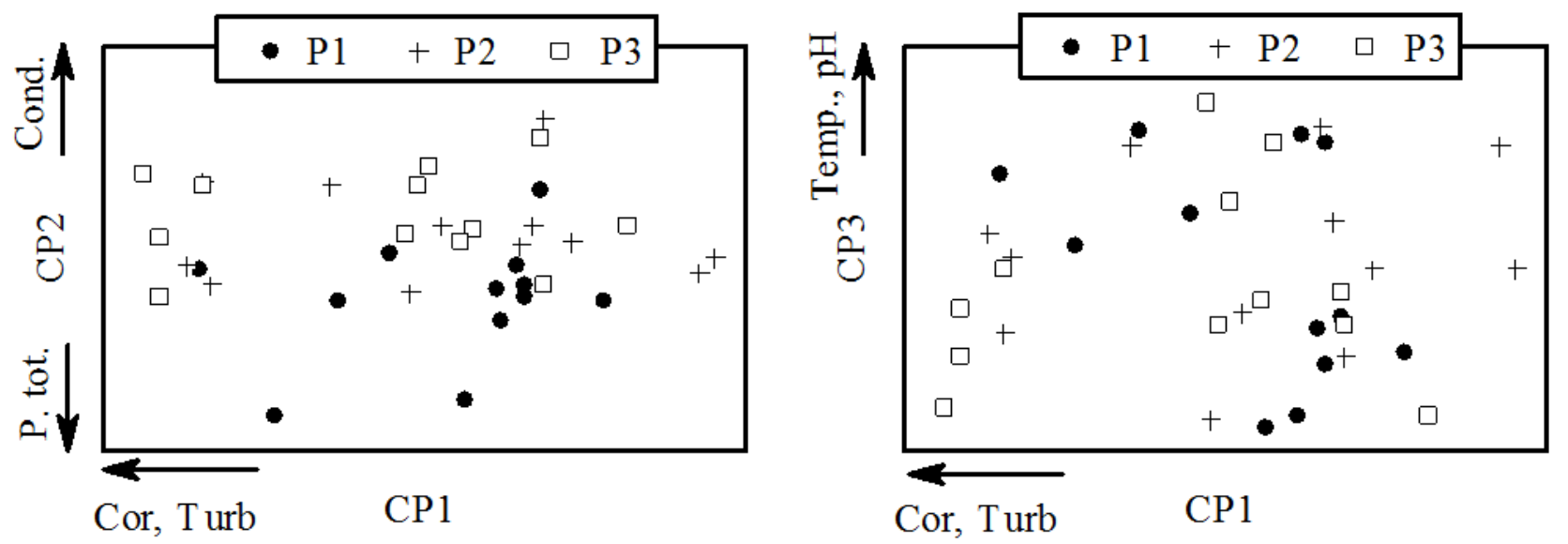

* Turb.: turbidly; Cond.: electrical conductivity; P. total: total phosphorus; Temp.: temperature.

FIGURE 2. Correlations between the physical and chemical variables analyzed in the river Cascavel, Paraná in the period July 2010 to June 2011.

The axes retained in the ACP and rainfall was correlated with the values found for CT and CTe. None of these showed significant relation in both Pearson and Spearman tests $(p<0.05)$. 


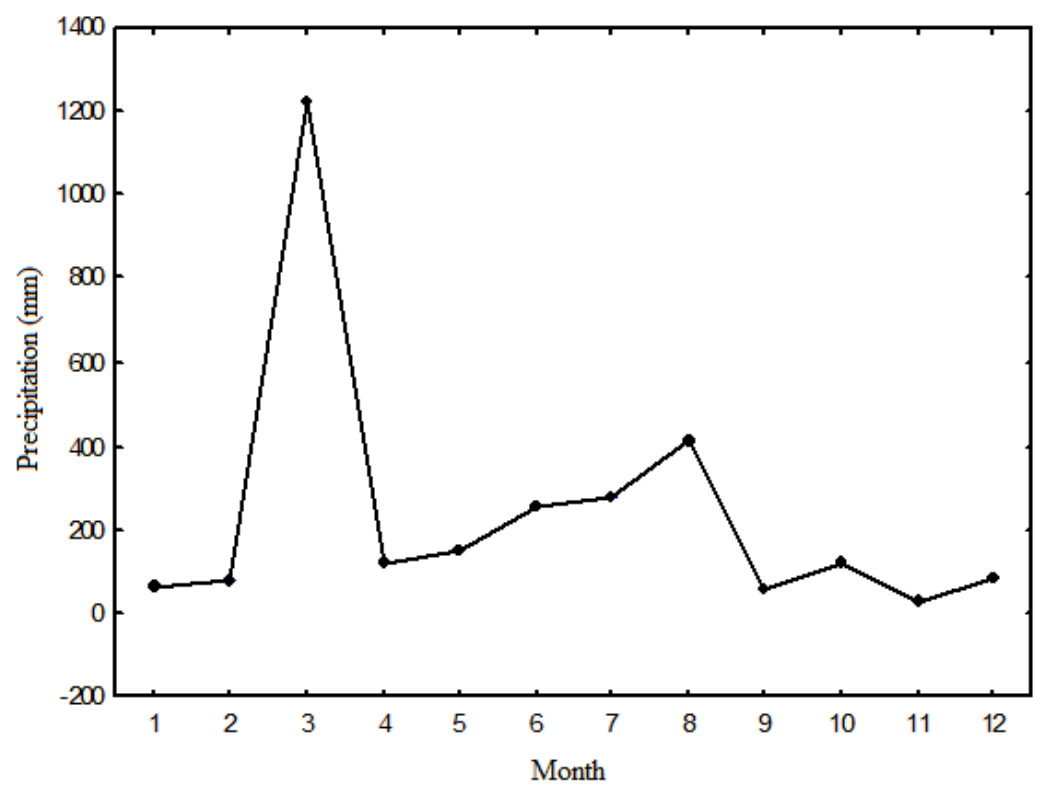

FIGURE 3. Mean values of monthly precipitation obtained in the months of collecting Cascavel River.

The physical, chemical factors and rainfall have no influence on the growth of groups of micro-organisms in this scale of study, being the months of highest precipitation values and CTe respectively September/2010 - February/2011 and November/2010 - May/2011 (Fig. 3 and 4). The relation between $\mathrm{CT}$ and physical and chemical variables of $\mathrm{pH}$, temperature, dissolved carbon and precipitation was observed by HONG et al. (2010) in a study performed in Pearl river, China, where the higher CT levels in the rainy season suggest that rainwater serves as an important carrier of micro-organisms in the reservoirs.

The differences obtained in this study may be attributed to the climatic characteristics of the region (typically subtropical climate) or the conservation status of the study area, suggesting that there are chronic source of pollution. OKADA et al. (2003) in conducted research on the plain of the Paraná River found that the interpretation of the effect of physical and chemical factors on micro-organisms changes over the months, depending on meteorological factors, seasonality, pollutant releases and discharges.

When comparing the concentrations of microorganisms between regions and monthly collections by analysis of variance, it was observed that the Point 2 had higher concentration of CTe in relation to point 1 . Both CT as the CTe showed higher concentrations at the end of spring season (November 2010). The other differences were not significant (Figure 4).

The higher counts of bacteria from the group of CTe in point 2 may be the result of urban pollution sources, which discharge into the river loads of garbage and waste without proper treatment. As the sewage of domestic origin are characterized by the presence of fecal material (ANA, 2011), can be considered that this source of pollution most influenced the micro biota of Cascavel river. WEBSTER et al. (2004) in a study conducted in rural and urban watersheds in the coastal plain of South Carolina also found significantly higher levels of CTe in the urban area. 

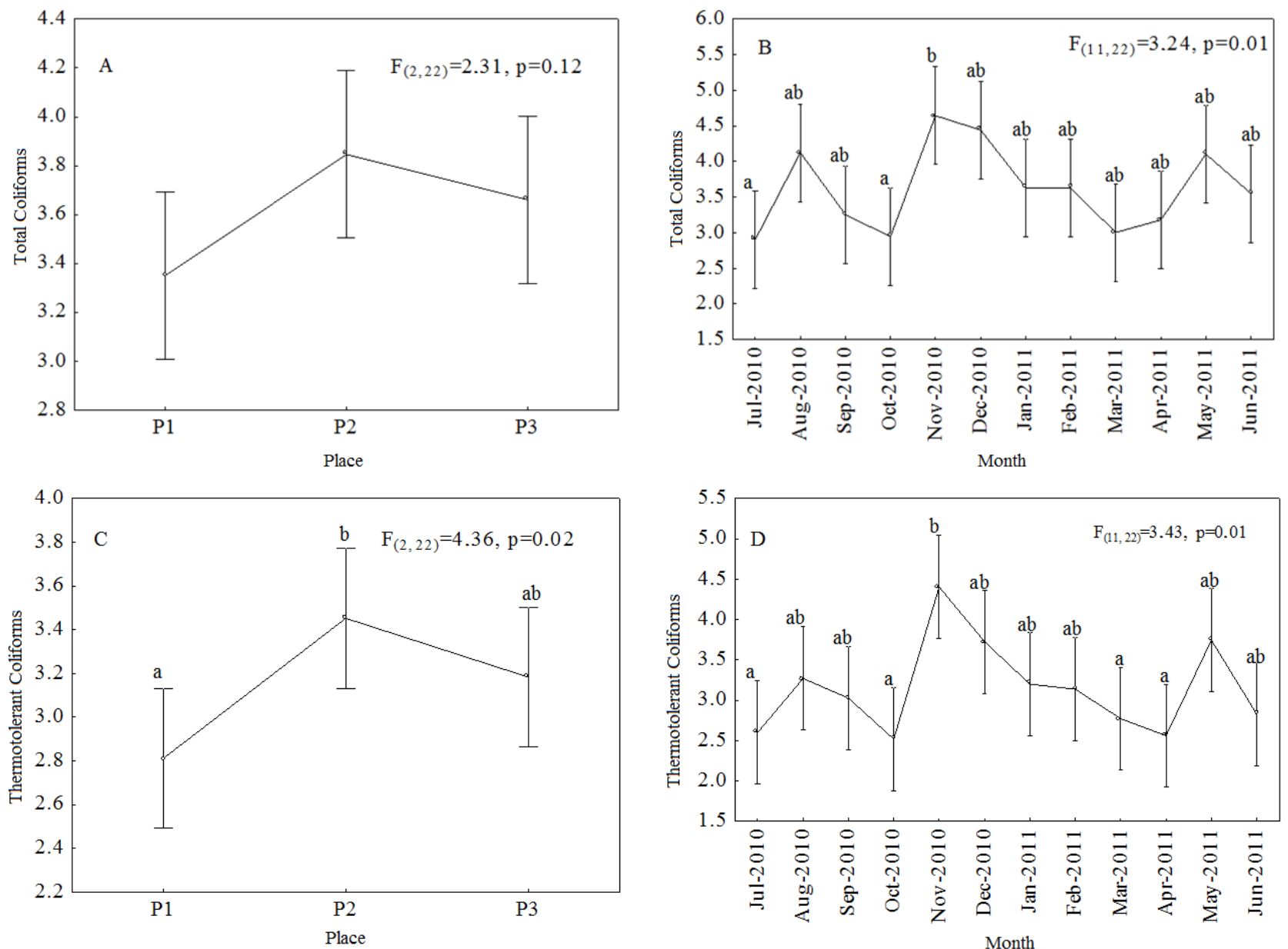

FIGURE 4. Mean values $\pm 95 \%$ confidence interval for the values of CT logaritimizados (A and B) and CTe (C and D) obtained in the regions (A and $\mathrm{C}$ ) and collection months (B and D) in the river Cascavel.

Despite of the higher counts of CT and CTe have been in the end of the spring season and in the beginning of the summer season, there was no significant relation with precipitation. As the $\mathrm{pH}$ values were between 6.5 and 7.5, the optimal growth of bacteria (RIGOBELO et al., 2009, the high scores of these months can be attributed to temperature variation, the other factor of great influence on the growth micro-organisms.

TABLE 2. Antimicrobial resistance profiles of strains of E. coli isolated from the river Cascavel, PR, Brazil.

\begin{tabular}{ccccccc}
\hline Profile & \multicolumn{2}{c}{$\mathrm{P} 1$} & \multicolumn{2}{c}{$\mathrm{P} 2$} & \multicolumn{2}{c}{$\mathrm{P3}$} \\
\hline AMP - EST - TET - PEN & $\mathrm{n}$ & $\%$ & $\mathrm{n}$ & $\%$ & $\mathrm{n}$ & $\%$ \\
AMP - TET - PEN & - & - & 1 & 12.5 & - & - \\
CFL - TET - PEN & 2 & 28.6 & 1 & 12.5 & - & - \\
TET - PEN & - & - & 1 & 12.5 & - & - \\
EST - PEN & 5 & 71.4 & 5 & 62.5 & 5 & 83 \\
$\mathrm{~N}^{0}$. of resistant to 1 antimicrobial & - & - & - & - & 1 & 17 \\
$\mathrm{~N}^{0}$ of resistant to 2 antimicrobial & - & - & - & - & - & - \\
$\mathrm{N}^{0}$ of resistant to 3 antimicrobial & 5 & 71.4 & 5 & 62.5 & 6 & 100 \\
$\mathrm{~N}^{0}$ of resistant to 4 antimicrobial & 2 & 28.6 & 2 & 25 & - & - \\
\hline
\end{tabular}

* AMP: ampicillin, EST: Streptomycin; TET: Tetracycline; PEN: Penicillin; CFL: Cephalothin.

The existence of large numbers of organisms in aquatic environments can facilitate the exchange of resistance determinants between bacterial groups (CARNEIRO et al., 2007; 
VASCONCELOS et al., 2010.). Strains of E. coli isolated from Cascavel River have different profiles of antimicrobial resistance (Table 2), and was observed at the site of greater urbanization (P2) higher prevalence of resistance. The fact that there are nearby homes to this sampling point may be a contributing factor for the identification of micro-organisms resistant to a greater number of drugs, namely ampicillin-streptomycin-penicillin-tetracycline (12.5\%). Similar results were found by MARTINHAGO et al. (2008) who evaluated the resistance profile of $E$. coli isolated from Lake City in Cascavel, PR, Brazil.

WEBSTER et al. (2004) in a study conducted in rural and urban watersheds in the coastal plain of South Carolina, found a high level of resistance in strains of E. coli (nalidixic-acid oxytetracycline-penicillin-streptomycin-ampicillin-tetracycline-sulfathiazole) probably due to contamination by point sources, because it is the area next to a sewage treatment plant.

The most common pattern of resistance to the isolates of E. coli were penicillin and tetracycline (16\% and $11 \%$, respectively)being all strains susceptible to sulphazotrim, imipenem, gentamicin, and chloramphenicol. Penicillin resistance can be related to the popularity of this antimicrobial prescribing in this region, both for humans and for pets, while high rate of tetracycline resistance is probably due to selection pressure exerted by antibiotic use in animal production and intensive livestock, since tetracycline is indicated in various diseases caused by Gram-negative bacteria therapy (WEBSTER et al., 2004).

The indiscriminate use of antimicrobials exposes humans and animals to various risks, such as selection of resistant bacteria in the aquatic environment; changes in the micro biota of growing environments and transfer of resistance to potentially pathogenic bacteria to humans (KÜMMERER, 2009). These antimicrobials can be inserted into the human food chain through ingestion of water by animals in the livestock sector, contaminated fish and irrigation in agriculture (CARNEIRO et al., 2007; SILVA et al., 2008; SCHNEIDER et al., 2009), which becomes increasingly important research to assess the origin of contamination of a wellspring.

Studies of the rate of antimicrobial resistance of strains of $E$. coli the most common use in the treatment of human infections may help in identifying the contamination of river water by discharges of sewage. WEBSTER et al. (2004) by determining the rate of antimicrobial resistance (IRA) classifies areas as wild and urban. The IRA for one sampling location (IRAp), classify the sampling sites as little affected, partially affected and affected by human actions. The lower the resulting value, smaller was antimicrobial resistance at that point (SILVA et al., 2010).

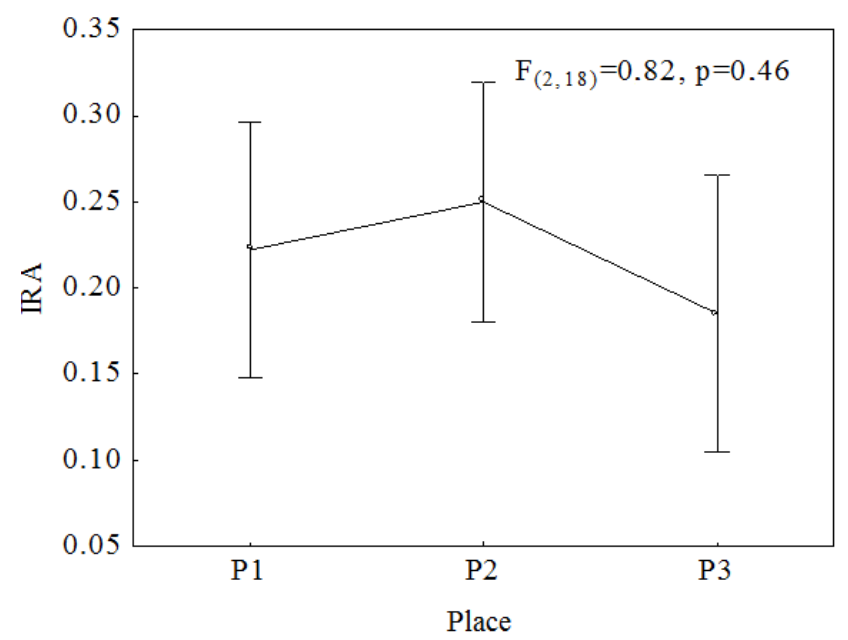

FIGURE 5. Mean values $\pm 95 \%$ confidence interval for the values observed in the ARI collection sites.

The concentration of CTe and results of IRAp were positively correlated, with the highest rate of IRAp observed at the point with the highest scores CTe (P2). When compared to P1 and P2, the 
P3 showed lower direct human influence and therefore lower IRAp. The data are consistent with a study by SILVA et al. (2010) that when analyzing river basin Passaúna-PR, found that low levels of IRAp characterized non-urbanized areas (low anthropogenic activity), suggesting that the E. coli were probably derived from wild animals.

The highest-resistant isolates a larger number of antimicrobials have been observed in P2 with an IRAp (0.24), which is a high value when compared to WEBSTER et al. (2004). Once this location is characterized as an area of high anthropogenic influence, the E. coli probably have human origin. It was found that the values of IRA calculated for each collection (IRAp) showed no statistical differences between sites by analysis of variance ( $<<0.05$, Figure 5 ).

In this context, it is suggested that the elimination and/or proper treatment of possible sources of diffuse pollution and point through changes in agricultural production, commercial, industrial and livestock, targeting products and waste less aggressive, need closer monitoring through the implementation of a better management of the watershed and public awareness of the problems caused to public health by water pollution.

\section{CONCLUSION}

The Cascavel river water presented itself at odds with the Ordinance 357/05 of CONAMA, national standards for quality of river water class I, as well as being rated in the regular category in IQA. Physical, chemical and precipitation variables did not influence the levels of growth of CTe and CT.

The interaction of physical, chemical and microbiological variables indicated that all sampling sites showed anthropogenic influence, which can categorize the variations of this influence with the most prevalent human activity in each point.

There was no significant statistical difference between points for CT, however for values CTe between P1 (water source) and P2 (urban area) is significant different.

The greatest resistance profiles found are related to micro-organisms isolated in P2, probably a result of influence point of the residences on the water quality.

\section{ACKNOWLEDGEMENT}

We thank the Itaipu Technological Park Foundation (FPTI) the granting of the scholarship.

\section{REFERENCES}

ANA. Agência Nacional de Águas. Disponível em:

http://pnqa.ana.gov.br/IndicadoresQA/IndiceQA.aspx. Acesso em: 25 de outubro de 2011.

ANDRADE, E.M.; ARAÚJO, L.F.P.; ROSA, M.F.; DISNEY, W.; ALVES, A.B. Seleção dos indicadores da qualidade das águas superficiais pelo emprego da análise multivariada. Engenharia Agrícola, Jaboticabal, v.27, n.3, p.683-690, 2007.

APHA. American Public Health Association - Standard Methods For the Examination of Water and Wastewater. $20^{\text {th }}$ ed. Washington: USA, 1998.

BRASIL. Ministério da Saúde. Secretaria de Vigilância em Saúde. Coordenação-Geral de Vigilância em Saúde Ambiental. Portaria Ministério da Saúde nº 2914, de 12 de dezembro de 2011. Diário Oficial da União, Brasília, Distrito Federal, 13 de dezembro de 2011.

BRASIL. Ministério do Meio Ambiente. Conselho Nacional do Meio Ambiente. Resolução CONAMA n ${ }^{\circ}$ 357, de 17 de março de 2005. Diário Oficial da União, Brasília, Distrito Federal, 17 de março de 2005.

CARNEIRO, D.O.; FIGUEIREDO, H.C.P.; PEREIRA JÚNIOR, D.J.; LEAL, C.A.G.; LOGATO, P.V.R. Perfil de susceptibilidade a antimicrobianos de bactérias isoladas em diferentes sistemas de 
cultivo de tilápia-do-nilo (Oreochromis niloticus). Arquivo Brasileiro de Medicina Veterinária e Zootecnia, Belo Horizonte, v.59, n.4, p.869-876, 2007.

CASCAVEL. Portal do município de Cascavel. Disponível em: http://www.cascavel.pr.gov.br/indicadores.php . Acesso em: 23 de julho de 2011.

CETESB. Companhia de Tecnologia Ambiental do Estado de São Paulo. Disponível em: http://www.cetesb.sp.gov.br/userfiles/file/agua/aguas-superficiais/aguasinteriores/documentos/indices/02.pdf. Acesso em: 16 de junho de 2013.

CLINICAL AND LABORATORY STANDARD INSTITUTE (CLSI). Performance Standards for Antimicrobial Susceptibility Testing: Nineteenth Informational Supplement (M100-S19). Clinical and Laboratory Standards Institute, Wayne: PA, 2007.

CORADI, P.C.; FIA, R.; PEREIRA RAMIREZ, O. Avaliação da qualidade da água superficial dos cursos de água do município de Pelotas - RS, Brasil. Ambiente e Água, Taubaté, v.4, n.2, 2009.

CREPALLI, M.S. Qualidade da água do rio Cascavel. 2007. 77 f. Dissertação (Mestrado em Engenharia Agrícola) - Universidade Estadual do Oeste do Paraná, Centro de Ciências Exatas e Tecnológicas, Cascavel, 2007.

GONÇALVES, E.M. Avaliação da qualidade da água do rio Uberabinha - Uberlândia - MG. 2009. 159f. Dissertação (Mestrado Tecnologia dos Processos Químicos e Bioquímicos) Universidade Federal do Rio de Janeiro, Escola de Química, Rio de Janeiro, 2009.

GONCHARUK, V.V. The concept of choosing a list of indices and their regulatory values for determination of hygienic requirements and control over the drinking water quality in Ukraine. Journal of Water Chemistry and Technology, Kiev, Ukraine, v.29, n.4, p.297-356, 2007.

HONG, H.; QIU, J.; LIANG, Y. Environmental factors influencing the distribution of total and fecal coliform bacteria in six water storage reservoirs in the Pearl River Delta Region, China. Journal of Environmental Sciences, Madrid, v.22, n.5, p.663-668, 2010.

KÜMMERER, K. Antibiotics in the aquatic environment -A review -Part I. Chemosphere, v.75, p.417-434, 2009.

LIBÂNIO, M. Fundamentos de qualidade e tratamento de água. Campinas: Átomo, 2005.

LUCAS, A.A.T.; FOLEGATTI, M.V.; DUARTE, S.N. Qualidade da água em uma microbacia hidrográfica do rio Piracicaba, SP. Revista Brasileira de Engenharia Agrícola e Ambiental, Campina Grande, v.14, n.9, p.937-943, 2010.

MANAHAN, S.E. Environmental Chemistry. 7.ed. Boca Raton (Florida-USA): CRC Press, 2006.

MARTINHAGO, M.W.; BUZANELLO, E.B.; ALMEIDA, M.M.; PINTO, F.G.S. Avaliação do perfil de susceptibilidade das cepas de Escherichia coli isoladas da água do lago municipal de Cascavel, Paraná. Revista Brasileira de Biociências, v.6, p.62-62, 2008.

MOURA, A.C.; ASSUMPÇÃO, R.A.B.; BISCHOFF, J. Monitoramento físico-químico e microbiológico da água do rio Cascavel durante o período de 2003 a 2006. Arquivos do Instituto Biológico, São Paulo, v.76, n.1, p.17-22, 2009.

NASH, M.S.; HEGGEM, D.T.; EBERT, D.; WADE, T.G.; HALL, R.K. Multi-scale landscape factors influencing stream water quality in the state of Oregon. Environmental Monitoring and Assessment, Beirut, v.156, n.1, p.343-360, 2009.

OKADA, E.K.A.A.; AGOSTINHO, M.; PETRERE, T. Factors affecting fish diversity and abundance in drying ponds and lagoons in the upper Paraná River basin. Ecohydrology \& Hydrobiology, Poland, v.3, n.1, p.97-110, 2003. 
OLIVEIRA, L.C.; GOMES, B.M.; BAUMGARTNER, G.; SEBASTIEN, N.Y. Variação espacial e temporal dos fatores limnológicos em riachos da microbacia do rio São Francisco Verdadeiro. Engenharia Agrícola, Jaboticabal, v.28, n.4, p.770-781, 2008.

PLUMMER, J.D.; LONG, S.C. Monitoring source water for microbial contamination: evaluation of water quality measures. Water Research, Oxford, v.41, p.3716-3728, 2007.

RIGOBELO, E.C.; MINGATTO, F.H.; TAKAHASHI, L.S.; ÁVILA, F.A. Padrão físico-químico e microbiológico da água de propriedades rurais na região de Dracena. Acadêmica Ciências Agrárias e Ambientais, Curitiba, v.7, n.2, p.219-224, 2009.

SCHÄFER, A.I.; ROSSITER, H.M.A.; OWUSU, P.A.; RICHARDS, B.S.; AWUAH, E. Physicochemical water quality in Ghana: Prospects for water supply technology implementation. Desalination, Oxford, v. 248, p.193-203, 2009.

SCHNEIDER, R. N.; NADVORNY, A.; SCHMIDT, V. Perfil de resistência antimicrobiana de isolados de Escherichia coli obtidos de águas superficiais e subterrâneas, em área de produção de suínos. Biotemas, Florianópolis, v.22, n.3, p.11-17, 2009.

SILVA, F.F.P.; SANTOS, M.A.A.; SCHMIDT, V. Resistência a antimicrobianos de Escherichia coli isolada de dejetos suínos em esterqueiras. Arquivo Brasileiro de Medicina Veterinária e Zootecnia, v.60, n.3, p. 762-765, 2008.

SILVA, N.; JUNQUEIRA, V.C.A.; SILVEIRA, N.F. Manual de métodos de análise microbiológica de alimentos. São Paulo: Varela, p.61-71, 32-38, 2007.

SILVA, T.F.B.X.; RAMOS, D.T.; DZIEDZIC, M.; OLIVEIRA, C.M.R.O.; VASCONCELOS, E.C. Microbiological quality and antibiotic resistance analysis of a brazilian water supply source. Water Air Soil Pollut, Netherlands, v.1, n.1, 2010.

VASCONCELOS, F.R.; REBOUÇAS, R.H.; EVANGELISTA-BARRETO, N.S.; DE SOUSA, O.V.; VIEIRA, R.H.S.F. perfil de resistência antimicrobiana de Escherichia coli isoladas do açude Santo Inácio, Ceará, Brasil. Arquivo do Instituto Biológico, v.77, n.3, p.405-410, 2010.

WEBSTER, L.F.; THOMPSON, B.C.; FULTON, M.H.; CHESTNUT, D.E.; VAN DOLAH, R.F.; LEIGHT, A.K. Identification of sources of Escherichia coli in South Carolina estuaries using antibiotic resistence analysis. Journal of Experimental Marine Biology and Ecology, Iran, v.298, p.179-195, 2004.

ZANINI, J.H.T.; AMARAL, L.A.; ZANINI, J.R.; TAVARES, L.H.S. Caracterização da água da Microbacia do Córrego Rico avaliada pelo índice de qualidade da água e de estado trófico.

Engenharia Agrícola, Jaboticabal, v.30, n.4, p.732-741, 2010. 